\title{
Business Factors related to Manufacturing Firms' Performance
}

\author{
Stergios Vranakis, Prodromos Chatzoglou \\ Department of Production \& Management Engineering, Democritus University of Thrace (Greece) \\ stergios@vranakis.gr,pchatzo@pme.duth.gr
}

Received: June 2013

Accepted: February 2014

\section{Abstract:}

Purpose: The main goal is to understand the way many factors affect the investment decision making process and business performance

Design/methodology/approach: This study proposes a new conceptual framework for examining the reasons that manufacturing firms decide to invest on the acquisition of new machinery and equipment in order to improve their infrastructure. It incorporates various factors related to the internal business environment (quality management, investment decisions etc.)

Findings: A new conceptual framework, establishing the relations between many factors, has been developed, allowing the determinants of adoption of many implications to be discussed and to relate them to the peculiarities of the Greek manufacturing industry.

Originality/value: This study presents an overview of the impact of machinery and equipment investment on firm's performance, giving grasp for further research of the interorganizational relationships that exist between them

Keywords: machinery \& equipment investments, firm performance, just in time, total quality management, supply chain management, environmental management 


\section{Introduction}

The selection of the suitable strategy cannot bring the desired results by itself (Porter, 1980). Firm and production strategies have to conform to one another and reflect the performance and environment of the firm. In the past few years, a vast amount of approaches-theories have been developed, regarding the improvement of the firms' operational performance (Kannan \& Tan, 2005). In particular, the enhancement of the manufactured product quality, direct response to market demands, the minimal delay on the firm's behalf and, of course, the minimal production cost, have been emphasized.

In the present study, a thorough review of the literature is realized, while the description of the research conceptual framework follows. Afterwards, the research methodology employed to achieve the research goals is described. Finally, the presentation of this study's outcomes and main conclusions are stated.

The basic aim of the study is to understand the way many factors affect the investment decision making process and to find out how machinery investments affect firm performance. The conceptual framework has never been studied before in the Greek industrial sector which has at its core the influence of investments on the performance of firms (Section I-1 \& I-4).

In the present study, a thorough review of the literature is realized, while the description of the research conceptual framework follows. Afterwards, the research methodology employed to achieve the research goals is described. Finally, the presentation of this study's outcomes and main conclusions are stated.

Results demonstrate that at both strategic and operational levels, linkages exist between all factors, which are viewed by organizations as part of their operations strategy. The sample frame for this study consisted of Greek firms that belong to the manufacturing sector of Greek economy.

\section{Literature review}

In recent years, numerous approaches have been proposed to improve firm performance. Six in particular: Just In Time, Total Quality Management, Supply Chain Management, Environmental Management and Investment Decisions have received considerable attention. The main purpose of the study is to find out how these factors affect firm performance through machinery investments (Section II-2). 


\subsection{Machinery and equipment investments}

Very few studies have been conducted to estimate the effect of machinery and equipment (M\&E) investments on firm performance. Delong and Summers (1991) and Sala-i-Martin (1997) in their studies, carried out in U.S.A. firms, define some econometric indices for the materialisation of machinery and equipment investments. Sargent and James (1997) make an attempt to empirically evaluate the effect of the firms' invested capital on their development, by taking into account the influence of machinery and equipment on firm development, at the same time. Being based on the studies of Delong and Summers (1991) and Sala-i-Martin (1997), they conclude that the knowledge and experience of the firm's administration has a strong and direct effect on machinery and equipment investments. Abdi (2008) concludes that machinery and equipment investments positively affect the production process levels, as well. The same statement is supported by Gort, Greenwood and Rupert (1999), who state that the development of technology positively affects $M \& E$ investments, by impelling firms to modernise.

DeLong and Summers (1991) discovered a strong, positive relationship between the firms' financial outcomes and machinery and equipment investments. Sala-i-Martin (1997) supported the view of the aforementioned researchers and found that the effect of machinery and equipment investments on the financial outcomes of a company is four times greater than it would be if the firm operated with the existing machinery. Finally, Jalilian and Odedokun (2000) empirically tested the relationship among the development of various investment types by using data from 55 countries. The final conclusion of their research was that not all types of (machinery) investment plans contribute as crucially to the development of a firm.

\subsection{Just in time}

The main goal of just in time (JIT) is the enhancement of investment performance. This is accomplished by an increase in the firm's cash inflows and a reduction of its operational costs. An inflow increase can be achieved by providing the buyer with greater value through improved quality, greater flexibility, orders greater satisfaction and continuous improvements (Schonberger, 1986). Cost reduction is based on limiting every form of squandering, such as excessive inventory.

In general, the philosophy of JIT theory aims at the minimisation of product defectiveness, through the simplification of the production processes (Kannan \& Tan, 2005). Namely, to what extent a firm can accomplish to manufacture the exact amount of products demanded by the customers, in the minimum possible time, without stocking inventory in its warehouses. The achievement or not of just in time (JIT) is an intrafirm factor that determines the performance of the firm and depends on the management's decisions. 
The impact of the JIT strategy on the manufacturing performance of firms has been the subject or several studies. Such studies have shown that the use of the JIT method can contribute to sales increase (Callen, Fader \& Krinsky, 2000; Fulleron \& McWatters, 2001), product quality improvement (Lawrence \& Hottenstein, 1995) and manufacturing performance (White, Pearson \& Wilson, 1999). The JIT approach is, primarily, based on the production of small batches of products (Kannan \& Tan, 2005). The principle of small batch production is employed so that a monitored flow of materials can exist throughout the manufacturing process. Additionally, anticipatory production (demand forecast) is emphasised. When used correctly, all the above are some of the ways that can minimise or even (ideally) eliminate excess products or/and raw materials, decrease production costs and make the firm perform better.

\subsection{Total Quality Management}

Total Quality Management (TQM) focuses on plenty and different sides of quality management, since it deals with "the policies, processes and actions through which quality is maintained and developed" (Sobek \& Jimmerson, 2004). It is advised that the process in this context can be perceived as two relative sub-activities, one that relates to management for quality and the other to quality management (Sullivan \& Miller, 2003). Thus, TQM is different for the product itself from TQM for the process of marketing or/and the manufacture of the product (Grönroos, 2000).

Total quality management (TQM) allows firms to differentiate from the competition, in order to improve the quality of their manufactured products and decrease the total production cost (Tari, 2005). Similar to just in time (JIT), it affects the performance of a firm and is, clearly, an intrafirm factor, since it depends on the firm's management decision about whether this approach will be used or not.

The TQM approach, regardless of all the advantages it offers in a theoretical level (Sohal, Ramsay \& Samson, 1993; Maani, Putterill \& Sluti, 1994; James, 1996; Kanji, 1998; Lee, 1998; Quazi \& Padibjo, 1998), presents several problems during its implementation (Kanji, 1998; Quazi \& Padibjo, 1998; Joubert, 1998). Firms, in order to achieve a successful implementation of the TQM approach, have to take into consideration several criteria that affect this method (Easton \& Jarrell, 1998; Claver, Llopis \& Taris, 1999). According to Tari and Sabater (2004), quality management depends on factors, such as: leadership, employee training, employee participation, production process management, quality organisation and measurement with the use of certain indices for continuous improvement. The aforementioned factors of quality management are those elements that can affect the satisfactory performance of the firm and are not the same in every study, they vary from author to author (Saraph, Benson \& Schroeder, 1989; Badri, Davis \& Davis, 1995; Powell, 1995; Adam, Corbett, Flores, Harrison, Lee, Rho et al., 1997; Ahire, Golhar \& Waller, 1996; Hendricks \& Singhal, 1997; Grandzol \& 
Gershon, 1998; Quazi, Jemangin, Kit \& Kian, 1998; Das, Handfield, Calantone \& Ghosh, 2000).

\subsection{Supply Chain Management}

The theory of Supply Chain Management (SCM) is an approach which refers to the coordination of decisions between firm suppliers and customers, with the aim to substantially improve the flow of the supply chain. The more the supply time of raw materials minimises, the quality of the manufactured products improves and the response of the firm optimises, the more effective the supply chain becomes, resulting in it positively affecting the performance of the firm.

Supply chain management is the process of design, development and monitoring of the production processes of the supply chain, which has as a primary goal the satisfaction of the firm customer requirements in the most effective way possible (Larson \& Rogers, 1998). From manufacturing the product till it reaches the hands of the final recipient (consumer), the product goes through middle suppliers (such as importers), increasing its final price to the customer. This approach aims at reducing these mediating phases, so the product's price remains in low and competitive levels.

The proper supply chain management requires reduction of intermediate suppliers (Krause, 1997), development of alliances with suppliers (Copacino, 1996; Mason, 1996), good collaboration with customers and suppliers (Watts \& Hahn, 1993), and customers' and suppliers' opinions to be taken into account throughout the development process of a product, by making the best of their experience and therefore, avoid choices that could possibly harm the firm (Monczka, Peterson, Handfield, \& Ragatz, 1998; Ragatz, HandGeld \& Scannell, 1997).

The above method of product management through supply chain is similar to the notion of integrated logistics systems (Lambert, Stock \& Ellram, 1998; Bowersox \& Closs, 1996) where, the organisation of product promotion (by reducing the intermediating suppliers), and also the participation of the firm's associates during the decision making process (regarding the development of new products, in manufacturing activities) is, in this case as well, emphasised.

\subsection{Investment Decisions}

The making of strategic Investment Decisions (ID) in new technology is difficult (Tan, Lim, Platts \& Koay, 2006). New technologies are usually expensive, affected by numerous factors and the likeliness of profit is usually hard to be determined in advance. Such decisions are 
based on intuition and experience and do not guarantee a certain outcome; for that reason the executive managers do not always use their knowledge of previous experiences.

According to Bernard and Leroy (2004), firm investment decisions are based on financial motives that are related to either the certain development phase the firm is at, or the purchase cost depreciation time of the firm's obtained equipment by the materialisation of this particular investment. The more unstable and competitive the business environment gets, the more uncertain the forecasts of future profits appear and at the same time, more stagnant the firms' productive investment projects become. Finally, a crucial element of productive investment decision making is for the firm's initial financial forecasts to be disproved of.

\subsection{Environmental Management}

The environment constitutes a source of the resources an individual, and by extension an organisation, can obtain. Firms have to follow proper Environmental Management (EM), in order to gain competitive advantages against similar firms (Porter, 1990). Firms need to understand and determine their strengths based on what they can obtain from the environment. The main problem they face is the instability and uncertainty the environment entails. The more the firm environment changes, the more the uncertainty increases (Song, 2001).

The environment which a company is surrounded involves the air, water, land, natural resources, human resources and everything related to them (Tam, Tam, Kenneth \& Cheung, 2006). Millions of noncompliance and complaint cases have been reported over the past few years and there is an increasing tendency of recording them (EPD, 2004). The external environment of a firm starts from the firm itself and extends to the universal system. The impact environmental pollution has on the overall life cycle of the production process is a serious problem for construction companies (Polster, Peuportier, Sommereux, Pedregal, Gobin \& Durand, 1996; Morledge \& Jackson, 2001), and presents a notable challenge to firm enhancement. Environmental management in industry has become a matter of discussion just in the last decade (Shen \& Tam, 2002; Tam, Tam \& Zeng, 2002). Unfortunately, the willingness to protect the environment remains weak for a lot of industrialised countries all over the world.

The past few years firms realised the importance of following a proper environmental policy, resulting in them investing more and more money in order to avoid environmental pollution (Huang \& Shih, 2010). The government of Hong Kong has proceeded to a green manager scheme and eco-business awards in 1995 and 1999 (Tam et al., 2006). The determination of environmental protection is not the same for every firm. 


\section{Proposed conceptual framework and research hypotheses}

The model is a composition of survey conclusions and views of many researchers who have dealt with these particular issues. According to Meliciani (2000), there is a positive relationship between firm performance and machinery and equipment investments. Most studies that deal with firm investment decisions are carried out in a sole country in order the investment and development motives to be the same throughout the research sample (Abdi, 2008). Finally, in Greece no research that has as its core the effect of investments on firm performance has been conducted. Based on all the above, we hypothesise:

\section{HYPOTHESIS 1: "Machinery and equipment investments" (M\&EI) have a positive effect on "Firm performance" (FPERF)}

The executive directors of a firm take responsibility for the riskiness of the investment decisions they make for the firm. According to the study of Sohn, Kim and Moon (2007b) and the literature they were based on (KOTEC, 2005; Sohn, Moon \& Kim, 2005), six factors and variables were found to influence the investment decision of the executive directors, as well as the firm's financial performance. Sohn et al. (2007b) attempted to link the strategic investment decisions to the financial performance of firms and used variables like: executive directors' knowledge and experience, executive directors' operational capability, firm technology level, product merchandising ability, production performance, all of which positively affect the financial performance of the firm. Therefore, a more effective type of administration should be applied with the appropriate machinery and equipment investments, in order to improve the machinery itself and the firm's performance as well. Thus, the following hypotheses are derived:

HYPOTHESIS 2a: The making of appropriate "investment decisions" has a positive effect on "firm performance".

HYPOTHESIS 2b: The making of appropriate "investment decisions" has a positive effect on "machinery and equipment investments".

Tam et al. (2006) concluded that the determination of personnel management and education, regarding the environmental management is the most important factor for the implementation of EM. Thus, the participation level of the administration managers of a firm is important for a successful implementation of EM (Bennett \& James, 1999a; Bennett \& James, 1999b; Kuhre, 1998). All the above can improve the total performance of firms and the outcomes they can inflict on the processes during production. The continuous renewal of the current equipment and technology can enhance the capabilities of a firm for innovation and environmental culture. Thus, based on the above, the following hypotheses, involving firm environmental management, occur: 
HYPOTHESIS 3a: The adoption of the right "environmental management" positively affects "firm performance".

HYPOTHESIS 3b: The adoption of the right "environmental management" positively affects "machinery and equipment investments".

The close relationship of the above theories and the apparent linkages among the JIT, TQM and SCM strategies state two main and critical questions: "Which of their elements correlate and how these correlations affect firm performance?" (Kannan \& Tan, 2005). The above theories represent alternative approaches for the improvement of the effectiveness and performance of some firm processes. Despite all these, the distinction of the JIT and TQM theories is unclear because they have common integral characteristics, like quality and performance (Snell \& Dean, 1992). It has been proven that both JIT and TQM methods are necessary for the improvement of manufacturing performance, with the TQM approach having the strongest impact on performance (Nakamura, Sakakibara \& Schoeder, 1997).

HYPOTHESIS 4: The adoption of the "just in time" (JIT) approach has a positive effect on "firm performance" (FPERF).

HYPOTHESIS 5: There is a positive relationship between "total quality management" (TQM) implementation and "firm performance" (FPERF).

HYPOTHESIS 6: The right implementation of "supply chain management" (SCM) has a positive effect on "firm performance" (FPERF).

The composition of the six research hypotheses, leads to the design of the Conceptual framework (Figure 1) of the present study, which is focused on the relationship among the research factors.

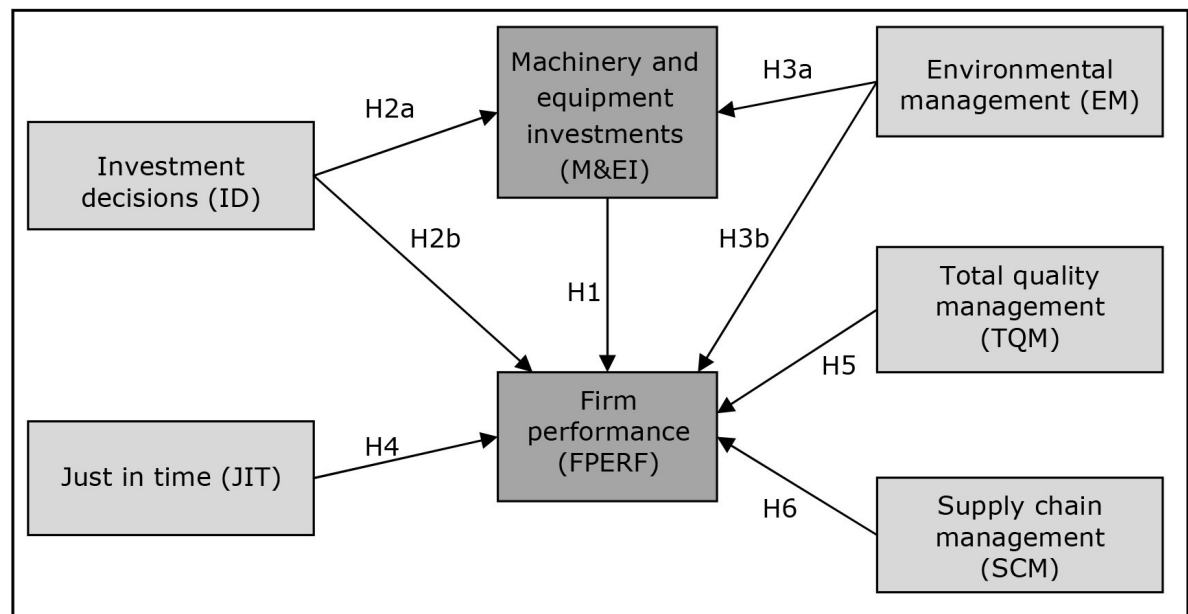

Figure 1. Proposed Conceptual Framework (Research Model) 


\section{Research Methodology}

\subsection{Population and research sample}

Greek industries, according to the statistical data of ICAP, entitled "Greek Economic Guide 2007", is characterized as most sectors of Greek economy, by the small-to-medium size of firms. Only $2 \%$ of the firms employ more than 500 people.

The sample of this study consisted of Greek firms that belong to the manufacturing sector of the Greek economy, and employ at least 20 employees. The sample data consists of 248 firms that have made investments during the past five years.

\subsection{Measurement of research factors}

A structured questionnaire was designed and utilized for the data collection. All constructs were measured using multiple items and all items (136 in total) were measured using a sevenpoint Likert-type scale ranging from one (very low) to seven (very high). The questionnaire is divided into nine sections. The first section refers to the general characteristics of the firm (industry, size, sales, market share and number of employees). The other eight sections contain questions concerning all the relevant model factors (machinery \& equipment investments, manufacturing flexibility, research and development, new product development, new product innovation, new product pricing policy, product life-cycle decision systems and firm performance. Table 1 presents all constructs, their factors and the number of items used to measure each construct along with the related literature (Section III-1).

Content validity was established through adopting a questionnaire pre-testing process (Zikmund, 2003). Pre-test participants (five managers and expert reviewers) were asked to comment on any difficulty or lack of clarity in the scale items and instructions. Some modifications were made (wording) in order to ensure that the original text was clearly interpreted in the target language, i.e. Greek. Then, the translated questionnaire was validated using the "back-translation" method, a process of translating back into the original language to ensure correspondence with the original version (Zikmund, 2003). Wording of questions was again slightly modified before the final format was established, based on remarks and suggestions offered by the pre-testing participants (Section III-1).

The measurement of each factor (concept) of the present study has been made with the use of multiple defining variables (questions). These defining variables were selected from international literature. For measuring all the defining variables the use of regular scales was employed. More precisely, the conceptual scale was used (Likert scale) (Section III-1). 
The complete form of the questionnaire consists of seven units. To measure the factors, 136 questions were used. The factors are shown at Table 1 . Table 1 presents all constructs, their factors and the number of items used to measure each construct along with the related literature (Section III-1).

\subsection{Data collection method}

The research was conducted from June to October of 2010. Overall, 768 questionnaires were sent (personally, electronically and by post), while 248 were returned completed. Ultimately, the response rate is around $32 \%$ and is considered satisfactory, especially when compared to the average of $20 \%$ that Young (1992) mentions for studies that are carried out on firms and are addressed to management executives. Thus, the sample of 248 firms can be considered representative.

\begin{tabular}{|c|c|c|c|}
\hline Factors & Latent variable & Measurement variable & References \\
\hline \multirow{3}{*}{$\begin{array}{l}\text { Machinery and } \\
\text { Equipment } \\
\text { Investments } \\
\text { (M\&EI) }\end{array}$} & External factors & $\begin{array}{l}\text { - Equipment investments effect positive at } \\
\text { commercial demands } \\
\text { - Equipment investments effect positive at logistic } \\
\text { problems } \\
\text { - Equipment investments effect positive at } \\
\text { environmental regulation } \\
\text { - Equipment investments effect positive at natural } \\
\text { causes like poor weather conditions }\end{array}$ & \multirow{3}{*}{$\begin{array}{l}\text { Abdi (2008), } \\
\text { Muchiri and } \\
\text { Pintelon (2008) }\end{array}$} \\
\hline & $\begin{array}{l}\text { Internal business } \\
\text { related factors }\end{array}$ & $\begin{array}{l}\text { - Equipment investments effect positive at } \\
\text { internal logistic problems } \\
\text { - Equipment investments effect positive at } \\
\text { organizational problems } \\
\text { Equipment investments effect positive at } \\
\text { projects within the plant }\end{array}$ & \\
\hline & $\begin{array}{l}\text { Internal operation- } \\
\text { related factors }\end{array}$ & $\begin{array}{l}\text { Production losses encountered in the cause of } \\
\text { running the plant } \\
\text { - Production losses encountered in the cause of } \\
\text { running the machinery }\end{array}$ & \\
\hline \multirow[t]{4}{*}{$\begin{array}{l}\text { Firm performance } \\
\text { (FPERF) }\end{array}$} & $\begin{array}{l}\text { Financial } \\
\text { performance }\end{array}$ & $\begin{array}{l}\text { - } \text { Sales growth } \\
\text { - } \text { Return on assets } \\
\text { - } \text { Return on sales } \\
\text { - } \quad \text { Performance success }\end{array}$ & \multirow{4}{*}{$\begin{array}{l}\text { Llorens, Molina } \\
\text { and Verdu } \\
\text { (2005), Sethi } \\
\text { and Sethi } \\
\text { (1990), Sohn et } \\
\text { al. (2007a) }\end{array}$} \\
\hline & Market performance & $\begin{array}{ll}\text { - } & \text { Market share } \\
\text { - } & \text { Return on assets } \\
\text { - Overall product quality } \\
\text { - Overall competitive position } \\
\text { Overall customer service levels }\end{array}$ & \\
\hline & $\begin{array}{l}\text { Technological } \\
\text { performance }\end{array}$ & $\begin{array}{l}\text { - Improvement of technological ability } \\
\text { - Technological progress } \\
\text { - } \quad \text { Lonquest of a technological gap } \\
\text { - Localization of a technology }\end{array}$ & \\
\hline & $\begin{array}{l}\text { Business } \\
\text { performance }\end{array}$ & $\begin{array}{l}\text { - Improvement of marketing } \\
\text { - New product development } \\
\text { - Localization of a product } \\
\text { - Improvement of company's popularity } \\
\text { - Sales and export increase }\end{array}$ & \\
\hline
\end{tabular}




\begin{tabular}{|c|c|c|c|}
\hline Factors & Latent variable & Measurement variable & References \\
\hline & $\begin{array}{l}\text { Management } \\
\text { performance }\end{array}$ & $\begin{array}{l}\text { - Improvement of employment } \\
\text { - Wage increase } \\
\text { - Improvement of R\&D environment } \\
\text { - Improvement of manufacturing environment }\end{array}$ & \\
\hline & $\begin{array}{l}\text { Manufacturing } \\
\text { performance }\end{array}$ & $\begin{array}{l}\text { - } \text { Product quality } \\
\text { - Improvement of a productivity } \\
\text { - Improvement of manufacturing cost } \\
\text { - }\end{array}$ & \\
\hline \multirow{3}{*}{$\begin{array}{l}\text { Just in time } \\
\text { (JIT) }\end{array}$} & Material flow & $\begin{array}{l}\text { - } \text { Reducing lot size } \\
\text { - } \text { Reducing setup time } \\
\text { - } \text { Increasing delivery frequency }\end{array}$ & \multirow{3}{*}{$\begin{array}{l}\text { Kannan and Tan } \\
(2005)\end{array}$} \\
\hline & Commitment to JIT & $\begin{array}{l}\text { - Increasing JIT capabilities } \\
\text { - Helping suppliers increase their JIT capabilities } \\
\text { pelecting suppliers striving to promote JIT } \\
\text { principles }\end{array}$ & \\
\hline & Supply management & $\begin{array}{l}\text { - } \text { Selecting suppliers striving to eliminate waste } \\
\text { - Reducing supplier base } \\
\text { - Preventive maintenance }\end{array}$ & \\
\hline \multirow{2}{*}{$\begin{array}{l}\text { Investment } \\
\text { decisions } \\
\text { (ID) }\end{array}$} & $\begin{array}{l}\text { Knowledge and } \\
\text { experience of } \\
\text { manager }\end{array}$ & $\begin{array}{l}\text { - Technology knowledge } \\
\text { - Technology experience }\end{array}$ & \multirow{2}{*}{$\begin{array}{l}\text { Sohn et al. } \\
(2005,2007 b)\end{array}$} \\
\hline & $\begin{array}{l}\text { Operation ability of } \\
\text { managers }\end{array}$ & $\begin{array}{ll}\text { - } & \text { Management ability } \\
\text { - } & \text { Fund supply } \\
\text { - Human resource }\end{array}$ & \\
\hline \multirow[t]{9}{*}{$\begin{array}{l}\text { Total quality } \\
\text { management } \\
\text { (TQM) }\end{array}$} & Leadership & $\begin{array}{l}\text { - Top management commitment and leadership } \\
\text { - Supervisory leadership } \\
\text { - } \quad \text { Public responsibility and citizenship }\end{array}$ & \multirow{9}{*}{$\begin{array}{l}\text { Kannan and Tan } \\
\text { (2005), Sila anc } \\
\text { Emprahimpour } \\
\text { (2005) }\end{array}$} \\
\hline & Strategic planning & $\begin{array}{l}\text { - } \text { Quality mission, goals and policy } \\
\text { - Strategy development } \\
\text { - } \quad \text { Strategy deployment }\end{array}$ & \\
\hline & Customer focus & $\begin{array}{l}\text { - } \text { Customer and market knowledgement } \\
\text { - } \text { Attention to customer satisfaction } \\
\text { - } \text { Management of customer relationships }\end{array}$ & \\
\hline & $\begin{array}{l}\text { Information and } \\
\text { analysis }\end{array}$ & $\begin{array}{l}\text { - Performance measurement and analysis } \\
\text { - Information management } \\
\text { - Use of information technology } \\
\text { - } \text { Quality tools } \\
\text { Benchmarking }\end{array}$ & \\
\hline & $\begin{array}{l}\text { Human resource } \\
\text { management }\end{array}$ & $\begin{array}{ll} & \text { Human resource management } \\
\text { - } & \text { Employee training } \\
\text { - } & \text { Employee satisfaction } \\
\end{array}$ & \\
\hline & $\begin{array}{l}\text { Process } \\
\text { management }\end{array}$ & $\begin{array}{l}\text { - Product and service design } \\
\text { - } \quad \text { Process control } \\
\text { - Innovation and continuous improvement of } \\
\text { processes, products and services }\end{array}$ & \\
\hline & $\begin{array}{l}\text { Supplier } \\
\text { management }\end{array}$ & $\begin{array}{ll}\text { - } & \text { Supplier quality } \\
\text { - } & \text { Supplier involvement } \\
\text { - } & \text { Supplier relationships }\end{array}$ & \\
\hline & Product design & $\begin{array}{l}\text { - } \text { Modular design of component parts } \\
\text { - } \text { Using standard components } \\
\text { - } \text { Designing quality into the product } \\
\text { - Considering manufacturability and assembly in } \\
\text { product design }\end{array}$ & \\
\hline & $\begin{array}{l}\text { Strategic } \\
\text { commitment to } \\
\text { quality }\end{array}$ & $\begin{array}{l}\text { Employee training in quality management and } \\
\text { control } \\
\text { - Empowerment of shop operators to correct } \\
\text { quality problems } \\
\text { - Top management communication of quality }\end{array}$ & \\
\hline
\end{tabular}




\begin{tabular}{|c|c|c|c|}
\hline Factors & Latent variable & Measurement variable & References \\
\hline & & $\begin{array}{l}\text { goals to the organization } \\
\text { Emphasizing quality instead of price in supplier } \\
\text { selection }\end{array}$ & \\
\hline & Supplier capability & $\begin{array}{l}\text { - Considering commitment to quality in supplier } \\
\text { selection } \\
\text { - Considering process capability in supplier } \\
\text { selection } \\
\text { - Considering commitment to continuous } \\
\text { improvement in supplier selection }\end{array}$ & \\
\hline \multirow{4}{*}{$\begin{array}{l}\text { Supply chain } \\
\text { management } \\
(\mathrm{SCM})\end{array}$} & $\begin{array}{l}\text { Supply chain } \\
\text { integration }\end{array}$ & $\begin{array}{l}\text { - Seeking new ways to integrate supply chain } \\
\text { management activities } \\
\text { - Improving integration of activities across supply } \\
\text { chain } \\
\text { - Reducing response time across supply chain } \\
\text { - Establishing more frequent contact with supply } \\
\text { chain members } \\
\text { - Creating compatible communication/info system } \\
\text { for supply chain members }\end{array}$ & \multirow{4}{*}{$\begin{array}{l}\text { Kannan and Tan } \\
(2005)\end{array}$} \\
\hline & $\begin{array}{l}\text { Supply chain } \\
\text { coordination }\end{array}$ & $\begin{array}{l}\text { Communicating your future strategic needs to } \\
\text { your suppliers } \\
\text { Creating a greater level of trust among supply } \\
\text { chain members } \\
\text { Identifying additional supply chains where firm } \\
\text { can establish a presence }\end{array}$ & \\
\hline & $\begin{array}{l}\text { Supply chain } \\
\text { development }\end{array}$ & $\begin{array}{l}\text { - Participating in sourcing decisions of suppliers } \\
\text { - Extending supply chain membership beyond } \\
\text { immediate suppliers and customers }\end{array}$ & \\
\hline & Information sharing & $\begin{array}{l}\text { - Using formal information sharing with suppliers } \\
\text { and customers } \\
\text { - Using informal information sharing with } \\
\text { suppliers and customers }\end{array}$ & \\
\hline
\end{tabular}

Table 1. Questionnaire of the research

\subsection{Content validity of the questionnaire}

Before conducting the research, content validity of the questionnaire took place. This analysis involves discussions with academics that deal with businesspeople and higher executive managers. Moreover, a pilot completion of the questionnaire was carried out on the aforementioned people. This process has allowed us to phrase the questions in a manner that is easily understood and thus, avoid inappropriate statements that lead to vagueness and general confusion of the person completing the questionnaire.

In order to assure construct validity of the research factors, an analysis of the unidimensional structure of the variables that compose every research factor, in addition to reliability analysis for each factor separately, was performed. For the realisation of this certain examination, Exploratory Factor Analysis with the method of principal components analysis was applied. Furthermore, to estimate the reliability of the research factors the statistical parameter Chronbach's Alpha was used.

The results that were derived from the analyses that were carried out (Table 2) allow us to claim that the defining variables compose concrete and reliable structures, capable of 
contributing to the estimation of the factor they belong to. To estimate the adaptability quality of the defining variables to the proposed factor models Confirmatory Factor Analysis was applied. Initially, analyses of the total model and then the structure model were performed.

\begin{tabular}{|c|c|c|c|c|c|c|}
\hline Factors & Sub-factors & Loadings & КMO & TVE & Bartlett's Test Sig. & Cronbach alpha \\
\hline \multirow{3}{*}{$\begin{array}{l}\text { Machinery and } \\
\text { equipment } \\
\text { investments }\end{array}$} & M\&EI1 & .752 & \multirow{3}{*}{.608} & \multirow{3}{*}{65.874} & \multirow{3}{*}{.000} & \multirow{3}{*}{.613} \\
\hline & M\&EI2 & .821 & & & & \\
\hline & M\&EI3 & .932 & & & & \\
\hline \multirow{4}{*}{ Investment Decisions } & ID1 & .866 & \multirow{4}{*}{.649} & \multirow{4}{*}{69.932} & \multirow{4}{*}{.000} & \multirow{4}{*}{.781} \\
\hline & ID2 & .892 & & & & \\
\hline & ID3 & & & & & \\
\hline & ID4 & .743 & & & & \\
\hline \multirow{3}{*}{ Just In Time } & JIT1 & .859 & \multirow{3}{*}{.500} & \multirow{3}{*}{73.847} & \multirow{3}{*}{.000} & \multirow{3}{*}{.644} \\
\hline & JIT2 & .859 & & & & \\
\hline & JIT3 & & & & & \\
\hline \multirow{10}{*}{$\begin{array}{l}\text { Total Quality } \\
\text { Management }\end{array}$} & TQM1 & .835 & \multirow{10}{*}{.934} & \multirow{10}{*}{67.918} & \multirow{10}{*}{.000} & \multirow{10}{*}{.931} \\
\hline & TQM2 & .830 & & & & \\
\hline & TQM3 & .721 & & & & \\
\hline & TQM4 & .903 & & & & \\
\hline & TQM5 & .842 & & & & \\
\hline & TQM6 & .899 & & & & \\
\hline & TQM7 & & & & & \\
\hline & TQM8 & & & & & \\
\hline & TQM9 & .724 & & & & \\
\hline & TQM10 & .819 & & & & \\
\hline \multirow{3}{*}{$\begin{array}{l}\text { Supply Chain } \\
\text { Management }\end{array}$} & SCM1 & .883 & \multirow{3}{*}{.500} & \multirow{3}{*}{77.905} & \multirow{3}{*}{.000} & \multirow{3}{*}{.702} \\
\hline & SCM2 & .883 & & & & \\
\hline & SCM3 & 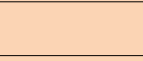 & & & & \\
\hline \multirow{7}{*}{$\begin{array}{l}\text { Environmental } \\
\text { Management }\end{array}$} & EM1 & .889 & \multirow{7}{*}{.893} & & & \\
\hline & EM2 & .828 & & & & \\
\hline & EM3 & .716 & & & & \\
\hline & EM4 & .838 & & 66.814 & .000 & .899 \\
\hline & EM5 & .830 & & & & \\
\hline & EM6 & .793 & & & & \\
\hline & EM7 & & & & & \\
\hline & FPERF1 & .704 & & & & \\
\hline & FPERF2.1 & .820 & & & & \\
\hline Firm nerformance & FPERF2.2 & .803 & 705 & 52525 & 000 & 640 \\
\hline rirm pertormance & FPERF3 & .841 & .105 & 52.525 & .000 & .649 \\
\hline & FPERF4 & .849 & & & & \\
\hline & FPERF5 & .850 & & & & \\
\hline
\end{tabular}

Table 2. Unidimensionality and reliability analysis 
For completing this particular testing the Exploratory Factor Analysis was employed with the method of Principle Components Analysis. Furthermore, for evaluating the reliability of the research factors the Cronbach Alpha index was used. The results that arise from the analyses that were carried out (Table 2) allow us to claim that the defining variables are solid, reliable constructs, capable of contributing to measuring the factor they belong to. In order to evaluate the adjustment quality of the defining variables to the proposed factor models, the Confirmatory Factor Analysis was employed. Initially, the complete model was tested and then, the structural model (Section II-5).

All the analyses that were performed for the adjustment of the data to the proposed model have provided satisfactory results. After the completion of the construct validity of the research factors, each one of the structures was defined as the average value of the defining items of which it consists.

According to Malhotra (1999) for factor analysis to apply: (i) the KMO indicator must have values over 0.6, (ii) the significance of Bartlett's test of sphericity must be lower than 0.05, (iii) VE must be bigger than $60 \%$ and (iv) the loadings of every variables must be higher than 0.7. It is easily confirmed that the examined indicators fulfill the above requirements and therefore can be used to further examine the model and test the research hypotheses. It must be stressed that for factors with two variables KMO values higher than 0.5 are accepted (Malhotra, 1999). Cronbach's alpha (a) is employed to test instrument reliability. According to Nunnally (1978) any value above 0.7 indicates reliability. The results show that all factors range between 0.612 and 0.923 , which surpasses the criteria of reliability.

In this study confirmatory factor analysis (CFA) was used to assess each factor's construct validity. Four fit measures were used to evaluate the model fit: chi-quare/degree of freedom (x2/d.f.), goodness-of-fit index (GFI), comparative fit index (CFI), and root mean square residual (RMR). The level of all the above indexes was within acceptable range indicating good fit of the measurement model (Section II-5).

Table 3 presents the model fit results for all (seven) research constructs. As can be seen, all loadings are above 0.6 (threshold 0.5, Bergeron, Raymond \& Rivard, 2004), chi-square/degree of freedom (x2/d.f.) scores are close to the accepted threshold score 5 (Harrison \& Rainer, 1996) for most of the constructs, GFI scores are above the 0.92 threshold (Bollen \& Long, 1993), CFI scores are also above the 0.9 threshold (Smith \& McMillan, 2001), while RMR values are below the 0.1 threshold (Bollen, 1989; Hair, Anderson, Tatham \& Black, 1992) (Section II-5). 


\begin{tabular}{|l|l|l|l|l|l|l|}
\hline \multicolumn{1}{|c|}{ Factors } & X2/df & RMR & GFI & \multicolumn{1}{c|}{ CFI } & \multicolumn{1}{c|}{ CR } & \multicolumn{1}{c|}{ VE } \\
\hline Machinery \& Equipment Investments (M\&EI) & 0.000 & .000 & 1.000 & 1.000 & 0.93 & 0.87 \\
\hline Investment Decisions (ID) & 0.000 & .000 & 1.000 & 1.000 & 0.87 & 0.70 \\
\hline Just In Time (JIT) & 0.000 & .000 & 1.000 & 1.000 & 0.85 & 0.74 \\
\hline Total Quality Management (TQM) & 3.032 & .011 & 0.932 & 0.972 & 0.94 & 0.68 \\
\hline Supply Chain Management (SCM) & 0.000 & .000 & 1.000 & 1.000 & 0.88 & 0.78 \\
\hline Environmental Management (EM) & 2.625 & .013 & 0.971 & 0.983 & 0.92 & 0.67 \\
\hline Firm Performance (FPERF) & 0.984 & .003 & 0.990 & 1.000 & 0.92 & 0.66 \\
\hline
\end{tabular}

Table 3. Confirmatory Factor Analysis

\section{Research Methodology}

After the completion of the confirmatory factor analysis that proceeded, the examination of the hypotheses of the proposed conceptual framework followed. In Table 4, the results of the structural model are stated. To test the research hypotheses the method of hierarchical moderated regression analysis was used (Russell \& Bobko, 1992). According to Pedharuz \& Schmelkin (1991) this particular statistical analysis is the most appropriate in the case of relatively small samples, because the indices it produces have satisfactory interpretation value. Thus, based on the constructed Research Model (Diagram 1), the examination of the corresponding hypotheses was done (Hypotheses 1, 2a, 2b, 3a, 3b, 4, 5 and 6).

\begin{tabular}{|l|c|c|c|c|}
\hline \multicolumn{1}{|c|}{ Independent Variable } & \multicolumn{2}{c|}{$\begin{array}{c}\text { Firm performance } \\
\text { (FPER) }\end{array}$} & \multicolumn{2}{c|}{$\begin{array}{c}\text { Machinery \& Equipment } \\
\text { Investments (M\&EI) }\end{array}$} \\
\hline Dependent Variables & $\mathrm{B}$ & $\mathrm{t}$ & $\mathrm{B}$ & $\mathrm{t}$ \\
\hline Investment Decisions (ID) & 0.137 & $2.288^{* *}$ & 0.265 & $2.371 * *$ \\
\hline Environmental Management (EM) & -0.068 & -1.029 & -0.471 & $-4.767 * * *$ \\
\hline Just In Time (JIT) & 0.065 & 1.611 & & \\
\hline Machinery \& Equipment Investments (M\&EI) & 0.115 & $3.732 * * *$ & & \\
\hline Total Quality Management (TQM) & 0.250 & $2.793 * *$ & & \\
\hline Supply Chain Management (SCM) & 0.220 & $3.765 * * *$ & & $11.853 * * *$ \\
\hline F-value & $42.346 * * *$ & & 0.089 \\
\hline$R^{2}$ & \multicolumn{2}{|c|}{0.514} & \\
\hline
\end{tabular}

$* * * \mathrm{p}<0.01, * * \mathrm{p}<0.05, * \mathrm{p}<0.10$

Table 4. Summary the of Hierarchical Moderated Regression Analysis

Therefore, in summary, we have: Hypotheses 1, 2a, 2b, 3b, 5 and 6 are supported by the data, while hypotheses $3 a, 4$ are not supported by the data.

Hypothesis 1 is the "core" of the present research work, since it examines the effect of investments in machinery and equipment on the performance of firms. This hypothesis is well- 
supported since there is a statistically important positive relationship between these two factors.

As it appears from Table 4, statistically important relationships develop between investment decisions (ID) and firm performance (FPERF) $(\beta=0.14, t=2.29, p<0.05)$, total quality management (TQM) and firm performance (FPERF) $(\beta=0.25, t=2.79, p<0.05)$ as well, and supply chain management (SCM) and firm performance (FPERF) $(\beta=0.22, t=3.77, p<0.01)$. Additionally, environmental management (EM) similarly appears to enhance machinery and equipment decisions (M\&EI) $(\beta=-0.27, t=-2.37, p<0.05)$. On the contrary, strong negatively important relationships have arisen between machinery and equipment investment (M\&EI) and firm performance (FPERF) $(\beta=-0.12, t=-3.73, p<0.05)$, as well as investment decisions and machinery and equipment investment (M\&EI) $(\beta=-0.47, \mathrm{t}=4.77, \mathrm{p}<0.01)$. Thus, hypotheses 1 , $2 a, 2 b, 3 b, 5,6$ are supported by the data.

Finally, the empirical results failed to verify hypotheses $3 a$ and 4 . Thus, it has not been found that just in time (JIT) and environmental management (EM) develop statistically important relationship to firm performance (FPERF) ( $p>0.10$ in both cases).

In summary, in this survey can be concluded in principle that investments in machinery (M\&EI) positively affect firm performance. Also that the environmental management (EM) has no effect on firm performance (FPERF), and has negative impact on machinery and equipment investments. One possible reason may be the environmental impact of industrial operation. Also Table 4 shows that Just in Time approach has no effect on firm performance. Maybe this is because JIT is too hard to be carried, either this approach is outdated. All the above findings in Table 4 are within acceptable statistical range (Section II-5 \& III-1).

\section{Conclusions}

In the presented model of this research, approaches influencing the performance of manufacturing firms, either positively or negatively, through machinery and equipment investments, were mentioned. This influence depends on how grave every firm considers each factor of the proposed model to be. This mixture of factors could possibly change depending on the gravity that is given to each factor and the type of the factor, as well. A lot of the suggestions for future research occur due to the recognition of the limitations of the present study. A different approach in measuring the factors could lead to different results (Section II$6)$.

The research results of the structure model evaluation support six (6) and reject two (2) hypotheses (see Table 4). Initially, the positive effect of machinery and equipment decisions on 
firm performance must be acknowledged. Although it can be considered as an expected result, its importance is great, considering the adverse conditions of the Greek business environment.

Green technology is increasingly becoming part of our everyday lives. Manufacturing firms have a lot of issues to deal with, in order to have a proper environmental operation. These issues are, for example the correct disposal of their waste (biological sewage treatment, water recycling systems, air ionization in production areas), the attempt to save resources (paper, raw materials and water) and the attempt to save energy by using renewable energy sources to cover their energy needs, as well. The cost of these resources, however, is quite high and, at this point, the training cost of the firm executives, regardless of management level, has to be added. In order to materialize these environmental investments, it is necessary to invest significant firm capital, and government grants are a great motive for firms, in order to obtain the necessary machinery.

TQM is a wide perspective that involves several areas, such as customer service management and quality services in total. There are, certainly, a lot of ways to explain quality in the context of business activity. TQM practically emphasizes, through constant improvement, innovation and adaptability, on the organization business needs. The firm has to establish and maintain processes for the recognition of the product during each phase of product manufacture and delivery.

In spite of the fact that most businesspeople recognize the importance of efficient SCM, they are not always willing to invest in bold and advanced solutions. Even in cases where investments are materialized, it is not obvious to what extend these investments are materialized based on rational criteria and decisions that derived after the adoption of a systematic approach. The implementation of best practices, like developing more precise forecasting and management supply chain systems, closely co-operating with suppliers and customers, real-time monitoring of the chain and ensuring great flexibility level, enables the prompt detection of problems and directs the correction actions that will need to be realized.

\subsection{Limitations and future research}

After observing the results of the research, it is useful to mention that the research was conducted with a sample of 248 firms which have implemented investments in the last five years. Even if they represent a significant percentage of the Greek firms that operate in the manufacturing field, the bigger the available sample would be, the better it would reflect the Greek reality.

In addition, due to the questions having subjective elements, some of the respondents could have overestimated a question by grading it 5 in Likert scale which could be "worth" 4 , or 
underestimated it by grading it 2 when it could be "worth" 3 . In order to extract the most objective responses possible, a lot of clarifying adjustments were made to the questionnaire.

Finally, a future research could benefit from the incorporation of other important factors in the research framework that has been developed in the present study. Factors, like business strategy and other internal and external factors influencing the firm can be added, since they affect and are significantly affected by investment firm movements.

\section{References}

Abdi, T. (2008). Machinery \& equipment investment and growth: evidence from the Canadian manufacturing sector. Applied Economics, 40(1), 465-478.

http://dx.doi.org/10.1080/00036840600690215

Adam, E., Corbett, L., Flores, B., Harrison, N., Lee, T., Rho, B., et al. (1997). An international study of quality improvement approach and firm performance. International Journal of Operations and Production Management, 9(17), 842-873.

http://dx.doi.org/10.1108/01443579710171190

Ahire, S.L., Golhar, D.Y., \& Waller, M.A. (1996). Development and validation of TQM implementation constructs. Decision Sciences, 27(1), 23-56. http://dx.doi.org/10.1111/j.15405915.1996.tb00842.x

Badri, M.A., Davis, D., \& Davis, D. (1995). A study of measuring the critical factors of quality management. International Journal of Quality \& Reliability Management, 12(2), 36-53. http://dx.doi.org/10.1108/02656719510080604

Bennett, M., \& James, P. (1999b). ISO 14031 and the future of environmental performance evaluation, in Sustainable Measures. Evaluation and Reporting of Environmental and Social Performance, Sheffield: Greenleaf Publications, 76-97. http://dx.doi.org/10.9774/GLEAF.978-1907643-19-4_4

Bennett, M., James, P. (1999a). The evolution of integrated environmental performance evaluation and reporting at Baxter international, in Sustainable Measures'. Evaluation and Reporting of Environmental and Social Performance, Greenleaf Publications, Sheffield, pp. 253-82. http://dx.doi.org/10.9774/GLEAF.978-1-907643-19-4_14

Bergeron, F., Raymond, L., \& Rivard, S. (2004). Ideal patterns of strategic alignment and business performance. Information and Management, 41(8), 1003-1020.

http://dx.doi.org/10.1016/j.im.2003.10.004 
Bernard J., \& Leroy S. (2004). Managers and productive Investment decisions: the impact of uncertainty and risk aversion. Journal of Small Business Management, 42(1), 1-18. http://dx.doi.org/10.1111/j.1540-627X.2004.00094.x

Bollen, K.A. (1989). Structural equations with latent variables. New York: Wiley.

Bollen, K.A., \& Long, J.S. (1993). Testing structural equation models. Newbury Park, CA: Sage

Bowersox D. J., Closs D.J. (1996). Logistical management: the integrated supply chain process. New York: McGraw-Hill.

Callen, J.L., Fader, C., \& Krinsky, I. (2000). Just in time: a cross sectional plant analysis. International Journal of Production Economics, 63(1), 277-301. http://dx.doi.org/10.1016/S09255273(99)00025-0

Claver, E., Llopis, J., \& Taris, J.J. (1999). Calidad y direccion de empresas. Madrid: Civitas.

Copacino, W.C. (1996). Seven supply-chain principles. TraBc Management, 35(1), 60-70.

Das, A., Handfield, R.B., Calantone, R.J., \& Ghosh, S. (2000). A contingent view of quality management - the impact of international competition on quality'. Decision Sciences, 31(3), 649-690. http://dx.doi.org/10.1111/j.1540-5915.2000.tb00938.x

Delong, B.J., \& Summers, L. (1991). Equipment investment and economic growth. Quarterly Journal of Economics, 106(1), 445-502.

Easton, G.S., \& Jarrell, S.L. (1998). The effects of total quality management on corporate performance, an empirical investigation. Journal of Business, 71(2), 253-307. http://dx.doi.org/10.1086/209744

EPD - Environmental Protection Department (2004). Hong Kong Environment 2004. Hong Kong Government, Hong Kong.

Fulleron, R.R, \& McWatters, C.S. (2001). The production performance benefits from JIT implementation. Journal Of Operations Management, 19(1), 81-96.

http://dx.doi.org/10.1016/S0272-6963(00)00051-6

Gort, M., Greenwood, J., \& Rupert, P. (1999). Measuring the rate of technological progress in structures. Review of Economic Dynamics, 2(1), 207-30. http://dx.doi.org/10.1006/redy.1998.0046

Grandzol, J.R., \& Gershon, M. (1998). A survey instrument for standardizing TQM modelling research. International Journal of Quality Science, 3(1), 80-105.

http://dx.doi.org/10.1108/13598539810203887

Grönroos, C. (2000). Service Management and Marketing. Chichester: Wiley \& Sons. 
Hair, J.F., Anderson, R.E., Tatham, R.L., \& Black, W.C. (1992). Multivariate data analysis with reading. New York: Macmillan Publishing Company.

Harrison, A.W., \& Rainer, R.K. (1996). A general measure of user computing satisfaction. Computers in Human Behavior, 12(1), 79-92. http://dx.doi.org/10.1016/0747-5632(95)00020-8

Hendricks, K., \& Singhal, V. (1997). Does implementing an effective TQM program actually improve operating performance? Empirical evidence from firms that have won quality awards. Management Science, 43(9), 1258-1274. http://dx.doi.org/10.1287/mnsc.43.9.1258

Huang, P.S., \& Shih, L.H. (2010). The impact of industrial knowledge management and environmental strategy on corporate performance of ISO 14000 companies in Taiwan: The application of structural equation modeling. African Journal of Business Management, 4(1), 21-30.

Jalilian, H., \& Odedokun, M.O. (2000). Equipment and non-equipment private investment: a generalized Solow model. Applied Economics, 32(3), 23-34.

http://dx.doi.org/10.1080/000368400322714

James, P. (1996). Total Quality Management: An Introductory Text. Englewood Cliffs, NJ: Prentice Hall.

Joubert, B. (1998). ISO 9000: international quality standards. Production and Inventory Management Journal, 39(2), 60-65.

Kanji, G.K. (1998). An innovative approach to make ISO 9000 standards more effective. Total Quality Management, 9(1), 67-78. http://dx.doi.org/10.1080/0954412989270

Kannan, V.R., \& Tan, K.C. (2005). JIT, TQM and SCM: understanding their linkages and impact on business performance. Omega, 33(1), 153-162. http://dx.doi.org/10.1016/j.omega.2004.03.012

Korea Technology Transfer Association - KOTEK (2005). Available at www.kotec.or.kr

Krause D.R. (1997). Supplier development: current practices and outcomes. International Journal of Purchasing and Materials Management, 33(2), 12-19. http://dx.doi.org/10.1111/j.1745493X.1997.tb00287.x

Kuhre, W.L. (1998). ISO 14031-Environmental Performance Evaluation (EPE): Practice Tools and Techniques for Conducting an Environmental Performance Evaluation. Prentice-Hall PTR, Upper Saddle River.

Lambert, D.M., Stock, J.R., \& Ellram, L.M. (1998). Fundamentals of logistics management. Homewood, IL, New York: Irwin, McGraw-Hill. 
Larson, P.D., \& Rogers, D.S. (1998). Supply chain management: definition, growth and approaches. Journal of Marketing, 6(4), 1-5.

Lawrence, J.J., \& Hottenstein, M.P. (1995). The relationship between JIT manufacturing and performance in Mexican plants affiliated with US companies. Journal of operations Management, 13(1), 3-18. http://dx.doi.org/10.1016/0272-6963(95)00018-N

Lee, T.Y. (1998). The development of ISO 9000 certification and the future of quality management: a survey of certification firms in Hong Kong. International Journal of Quality \& Reliability Management, 15(2), 162-177. http://dx.doi.org/10.1108/02656719810204766

Llorens, F.J, Molina, L.M., \& Verdu, A.J. (2005). Flexibility of manufacturing systems, strategic change and performance. International Journal of Production Economics, 98(1), 273-289. http://dx.doi.org/10.1016/j.ijpe.2004.05.011

Maani, K.E., Putterill, M.S., \& Sluti, D.G. (1994). Empirical analysis of quality improvement in manufacturing. Asia Pacific Journal of Quality Management, 3(1), 5-23.

Malhotra, N.K. (1999). Marketing Research. An Applied Orientation. International Edition. 3rd edition. London: Prentice Hall.

Mason, T. (1996). Getting your suppliers on the team. Logistics Focus, 4(1), 10-12.

Meliciani, V. (2000). The relationship between R\&D, investment and patents: a panel data analysis. Applied Economics, 32(11), 35-55. http://dx.doi.org/10.1080/00036840050151502

Monczka, R.M., Peterson, K.J., Handfield, R.B., \& Ragatz, G.L. (1998). Success factors in strategic supplier alliances: the buying company perspective. Decision Sciences, 29(3), 553-577. http://dx.doi.org/10.1111/j.1540-5915.1998.tb01354.x

Morledge, R., \& Jackson, F. (2001). Reducing environmental pollution caused by construction plant. Environmental Management and Health, 12(2), 191-206.

http://dx.doi.org/10.1108/09566160110389933

Muchiri, P., \& Pintelon, L., (2008). Performance measurement using overall equipment effectiveness (OEE): literature review and practical application discussion. International Journal of Production Research, 46(13), 3517-3535. http://dx.doi.org/10.1080/00207540601142645

Nakamura, M., Sakakibara, S., \& Schoeder, R.G. (1997). Adoption of just in time manufacturing at US and Japanese owned plants: some empirical evidence. IEEE Transactions on Engineering Management, 45(3), 230-240. http://dx.doi.org/10.1109/17.704245

Nunnally, J. C. (1978). Psychometric Theory. McGraw-Hill, New York. 
Pedhazur, E., \& Schmelkin, L. (1991). Measurement, Design and Analysis: An Integrated Approach. Hillsdale, NJ: Lawrence Erlbaum Associates.

Polster, B., Peuportier, B., Sommereux, I.B., Pedregal, P.D., Gobin, C., \& Durand, E. (1996). Evaluation of the environmental quality of buildings towards a more environmentally conscious design. Solar Energy, 57(3), 219-230. http://dx.doi.org/10.1016/S0038-092X(96)00071-0

Porter, M. (1980). Competitive Strategy: Techniques for Analyzing Industries and Competitors. New York: Free Press.

Porter, M. (1990). The Competitive Advantage of Nations. New York: Free Press.

Powell. T. (1995). Total quality management as competitive advantage: a review and empirical study. Strategic Management Journal, 16(1), 15-37. http://dx.doi.org/10.1002/smj.4250160105

Quazi, H.A., \& Padibjo, S.R. (1998). A journey toward total quality management through ISO 9000 certification - a study on small and medium-sized enterprises in Singapore. International Journal of Quality \& Reliability Management, 15(5), 489-508. http://dx.doi.org/10.1108/02656719810196225

Quazi, H.A., Jemangin, J., Kit, L.W., \& Kian, C.L. (1998). Critical factors in quality management and guidelines for self-assessment, the case of Singapore. Total Quality Management, 9(1), 35-55. http://dx.doi.org/10.1080/0954412989252

Ragatz, G.L., HandGeld, R.B., \& Scannell, T.V. (1997). Success factors for integrating suppliers into new product development. Journal of Production Innovation Management, 14(1), 190-202. http://dx.doi.org/10.1016/S0737-6782(97)00007-6

Russell, J.C., \& Bobko, P. (1992). Moderated Regression Analysis and Likert Scales Too Coarse for Comfort. Journal of Applied Psychology, 77(3), 336-342. http://dx.doi.org/10.1037/00219010.77.3.336

Sala-i-Martin, X. (1997). I just ran four million regressions. American Economic Review, 87(1), 178-183.

Saraph, J.V., Benson, P.G., \& Schroeder, R.G. (1989). An instrument for measuring the critical factors of quality management. Decision Sciences, 20(4), 810-829.

http://dx.doi.org/10.1111/j.1540-5915.1989.tb01421.x

Sargent, T., \& James, S. (1997). Potential Output, Productivity, and the New Growth Theory. Economic Studies and Policy Analysis Division, Department of Finance, Canada, November.

Schonberger, R.J. (1986). World class manufacturing: The lessons of simplicity applied. New York, N.Y.: The Free Press. 
Sethi, A K., \& Sethi, S.P. (1990). Flexibility in manufacturing: A survey. International Journal of Flexible Manufacturing Systems, 2(1), 289-328.

Shen, L.Y., \& Tam, W.Y. (2002). Implementation of environmental management in the Hong Kong construction industry. International Journal of Project Management, 20(7), 535-543. http://dx.doi.org/10.1016/S0263-7863(01)00054-0

Sila, M., \& Embrahimpour, M. (2005). Critical linkages among TQM factors and business results. International Journal of Operations \& Management, 15(11), 1123-1155. http://dx.doi.org/10.1108/01443570510626925

Smith, T.D. \& McMillan, B.F. (2001). A primer of model fit indices in structural equation model. In Paper presented at the annual meeting of the southwest educational research association, February 1-3, New Orleans, LA.

Snell, S.A., \& Dean, J.W. (1992). Integrated manufacturing and human resource management: A human resource perspective. Academy of Management Journal, 35(3), 467-504. http://dx.doi.org/10.2307/256484

Sobek, D.K., \& Jimmerson, C. (2004). A3 Reports: Tool for Process Improvement and Organizational Transformation. Proceedings of the 2004 Industrial Engineering Research Conference. Houston, TX.

Sohal, A.S., Ramsay, L., \& Samson, D. (1993). Quality management practices in Australian industry. Total Quality Management, 3(3), 283-299. http://dx.doi.org/10.1080/09544129200000035

Sohn, S.Y., Joo, Y.G., \& Han, H.K. (2007a). Structural Equation Model for the evaluation of national funding on R\&D project of SMEs in consideration with MBNQA criteria. Evaluation and Program Planning, 30(1), 10-20. http://dx.doi.org/10.1016/j.evalprogplan.2006.10.002

Sohn, S.Y., Kim, H.S., \& Moon, T.H. (2007b). Predicting the financial performance index of technology fund for SME using structural equation model. Expert Systems with Applications, 32(1), 890-898. http://dx.doi.org/10.1016/j.eswa.2006.01.036

Sohn, S.Y., Moon, T.H., \& Kim, S.H. (2005). Improved technology scoring model for credit guarantee fund. Experts System with Applications, 28(2), 327-331.

http://dx.doi.org/10.1016/j.eswa.2004.10.012

Song, S. (2001). City size and urban unemployment: Evidence from China. World Economy and China, 9(1), 46-53.

Sullivan, P., Miller, A. (2003). The new QAA framework and the EFQM excellence model: A way forward for universities. HESDA paper. 
Tam, C.M., Tam, W.Y., \& Zeng, S.X. (2002). Environmental performance evaluation for construction. Building Research and Information, 30(5), 349-361.

http://dx.doi.org/10.1080/09613210210150964

Tam, V., Tam, C., Kenneth, T.W., \& Cheung, S.O. (2006). Critical factors for environmental performance assessment (EPA) in the Hong Kong construction industry. Construction Management and Economics, 24(11), 1113-1123. http://dx.doi.org/10.1080/01446190600799620

Tan, K.H., Lim, C.P., Platts, K., \& Koay, H.S. (2006). An intelligent decision support system for manufacturing technology investments. International Journal of Production Economics, 104(1), 179-190. http://dx.doi.org/10.1016/j.ijpe.2005.02.010

Tari, J.J. (2005). Components of successful Total Quality Management. The Total Quality Management Magazine, 17(2), 182-194.

Tari, J.J., \& Sabater, V. (2004). Quality tools and techniques: Are they necessary for quality management. International Journal Production Economics, 92(1), 267-280.

http://dx.doi.org/10.1016/j.ijpe.2003.10.018

Watts, C.A., \& Hahn, C.K., (1993). Supplier development programs: an empirical analysis. International Journal of Purchasing and Materials Management, 24(2), 10-17.

http://dx.doi.org/10.1111/j.1745-493X.1993.tb00002.x

White, R.E., Pearson, J.N., \& Wilson, J.R. (1999). JIT manufacturing: a survey of implementations in small and large US manufacturers. Management Science, 45(1), 1-15. http://dx.doi.org/10.1287/mnsc.45.1.1

Young, A. (1992). A tale of two cities: Factor accumulation and technical change in Hong Kong and Singapore NBER Macroeconomics Annuals. MIT Press, Cambridge, MA.

Zikmund, W.G. (2003). Business research methods (7th ed.). Mason: Thomson/South-Western.

Journal of Industrial Engineering and Management, 2014 (www.jiem.org)

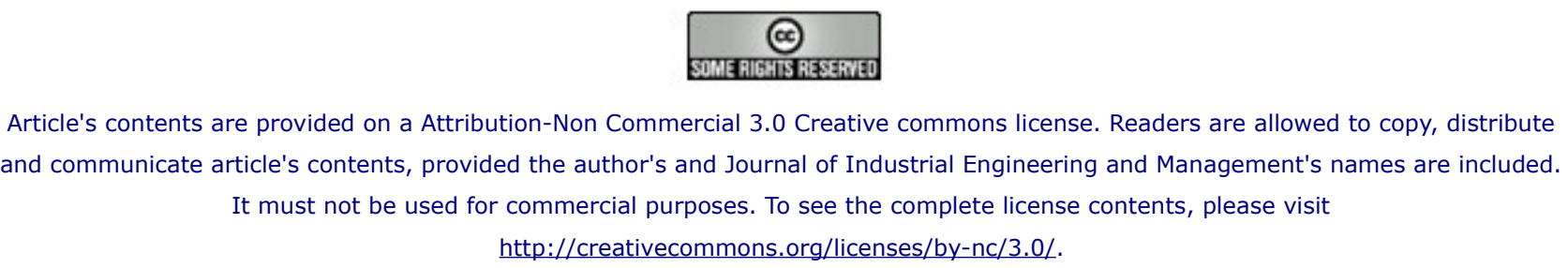

http://creativecommons.org/licenses/by-nc/3.0/. 